\title{
Chronic and Low Dose Exposure to Nonlyphenol or Di(2-Ethylhexyl) Phthalate Alters Cell Proliferation and the Localization of Steroid Hormone Receptors in Uterine Endometria in Mice
}

\author{
Juhye Kim¹, Sunyeong Cha ${ }^{1}$, Min Young Lee ${ }^{1}$, Yeon Jeong Hwang ${ }^{1}$, Eunhyeok Yang ${ }^{1}$, \\ Donchan Choi ${ }^{2}$, Sung-Ho Lee ${ }^{3}$, and ${ }^{\dagger}$ Yong-Pil Cheon ${ }^{1}$ \\ ${ }^{1}$ Division of Developmental Biology and Physiology, Dept. of Biotechnology, Sungshin University, Seoul 02844, Korea \\ ${ }^{2}$ Dept. of Life Science, College of Environmental Sciences, Yong-In University, Yongin 17092, Korea \\ ${ }^{3}$ Dept. of Biotechnology, Sangmyung University, Seoul 03016, Korea
}

\begin{abstract}
Based on our preliminary results, we examined the possible role of low-dose and chronic-exposing of the chemicals those are known as endocrine disrupting chemical (EDC), on the proliferation of uterine endometrium and the localization of steroid receptors. Immunohistochemical or immunofluorochemical methodology were employed to evaluate the localization of antigen identified by monoclonal antibody Ki 67 protein (MKI67), estrogen receptor 1 (ESR1), estrogen receptor 2 (ESR2), and progesterone receptor (PGR). In $133 \mu \mathrm{g} / \mathrm{L}$ and 1,330 $\mu \mathrm{g} / \mathrm{L}$ di(2-ethylhexyl) phthalate (DEHP) and 50 $\mu \mathrm{g} / \mathrm{L}$ nonylphenol (NP) groups, the ratio of MKI67 positive stromal cells was significantly increased but not in $500 \mu \mathrm{g} / \mathrm{L}$ NP group. The ratios of MKI67 positive glandular and luminal epithelial cells were also changed by the chronic administration of NP and DEHP in tissue with dose specific manner. ESR1 signals were localized in nucleus in glandular and luminal epithelia of control group but its localization was mainly in cytoplasm in DEHP and NP administered groups. On the other hand, it was decreased at nucleus of stromal cells in 1,330 $\mu \mathrm{g} / \mathrm{L}$ DEHP group. The colocalization patterns of these nuclear receptors were also modified by the administration of these chemicals. Such a tissue specific and dose specific localization of ESR2 and PGR were detected as ESR1 in all the uterine endometrial tissues. These results show that the chronic lows-dose exposing of NP or DEHP modify the localization and colocalization of ESRs and PGR, and of the proliferation patterns of the endometrial tissues.
\end{abstract}

Key words : Di(2-ethylhexyl) phthalate, Nonylphenol, Stromal cell, Epithelial cell, Steroid hormone receptors

\section{INTRODUCTION}

It has been documented that endocrine disrupting chemicals (EDCs) resemble action of steroid hormones and affect reproductive system at certain doses. As organic synthetic skill and need of plastics have been expanded, EDCs have been widely exposed to environment. Most of the studies about EDCs have focused on the toxicological concepts for decades. Recently EDCs are challenged in the view of physiological responses and reproductive tract disorders concerned with exposing doses and periods. Although low-dose exposure to a chemical which is known as an EDC is not considered toxic, as EDCs are ubiquitous, studies for chronic low-dose exposure to EDCs are necessary.

Nonylphenol (NP) and di(2-ethylhexyl) phthalate (DEHP, bis(2-ethylhexyl) phthalate) are well identified EDCs and

\footnotetext{
Manuscript received June 8, 2019, Received in revised form August 30, 2019, Accepted September 19, 2019

${ }^{\dagger}$ Corresponding Author: Yong-Pil Cheon, Ph.D., Division of Developmental Biology and Physiology, Dept. of Biotechnology, Sungshin University, Seoul 02844, Korea. Tel: +82-2-920-7639, Fax: +82-2-920-2736, E-mail: ypcheon@ sungshin.ac.kr

This is an Open Access article distributed under the terms of the Creative Commons Attribution Non-Commercial License (http:// creative-commons.org/licenses/by-nc/3.0) which permits unrestricted non-commercial use, distribution, and reproduction in any medium, provided the original work is properly cited.
} 
their known adverse effects are various by the experiments. Administration with $40 \mathrm{mg} / \mathrm{kg}$ body weight (BW)/day NP for 14 days on guinea pigs exhibited prevention of decrease in uterine weight following castration and estrogenic effects on histological features of castrated animals (Danzo et al., 2002). In ovariectomized (OVX) rats, NP at a dose of 100 and $200 \mathrm{mg} / \mathrm{kg}$ bw for 3 days increased uterine weights and thickness of endometrium, and induced proliferation of endometrial cells (Zhang et al., 2007). In immature female Sprague-Dawley rats, NP induced uterine growth at $1.0,2.0$, and $4.0 \mathrm{mg} / \mathrm{kg}$ bw, which is 1,000 to 2,000 folds less potent than $17 \beta$-estradiol $\left(\mathrm{E}_{2}\right.$, Lee \& Lee, 1996). In addition, its action was blocked by ESR antagonist, ICI 182,780, indicating that it was mediated through ESR. It has been verified that DEHP has reproductive toxicity in humans and animals (Lovekamp-Swan \& Davis, 2003; Lorz et al., 2012; Somasundaram et al., 2016). In vivo exposure to $2 \mathrm{~g} / \mathrm{kg}$ bw DEHP for 12 days on mature Sprague-Dawley rats decreased ovarian $\mathrm{E}_{2}$ production, prolonged estrous cycles, and stopped ovulation (Davis et al., 1994). In OVX rats, treatment of $1,000 \mathrm{mg} / \mathrm{kg}$ bw/day DEHP for 5 days did not have estrogenic activity, with no change in sex hormone levels, uterus estrogen receptor (ER) levels, uterine weight, and histopathology in uterus (Lorz et al., 2012). Oral exposure to 1, 10, and $100 \mathrm{mg} / \mathrm{kg}$ bw/day of DEHP on Wistar rats for 30 days did not change bw and uterine wet weight, but increased ovarian hormones and their receptors expression and decreased uterine diameter and numbers of uterine glands (Somasundaram et al., 2016). In vitro treatment with DEHP has suggested increased viability of endometrial stromal cells, a precondition to endometriosis (Scsukova et al., 2016). Another in vitro studies exhibited that DEHP competed with $\mathrm{E}_{2}$ for binding to rainbow trout hepatic ESRs (Jobling et al., 1995).

Lately, a study determining effects of DEHP on uterus of adult female CD-1 mice demonstrated that $200 \mu \mathrm{g} / \mathrm{kg} /$ day (for 30 days) reduced epithelial cell proliferation and increased numbers of uterine glands (Richardson et al.,
2018). We also reported the effect of chronic low-dose (for 10 weeks) DEHP and NP on the uterus. For example, the number of glands is increased in $133 \mu \mathrm{g} / \mathrm{L}$ DEHP but decreased in 50 and $500 \mu \mathrm{g} / \mathrm{L}$ NP groups (Kim et al., 2018). Estrogen has pleiotropic effects on ESRs and progesterone receptors (PGRs) in mouse uterus through interaction of steroid hormones. Therefore, the expression of the sex steroid hormone receptors in the uterine lumen is depend on the physiological status. It is well established that progesterone interregulation in uterine preparation for estrous cycle through its receptors and its dosage (Kurita et al., 1998; Tibbetts et al., 1998). Our early studies showed the different expression patterns by the NP and DEHP, although the physiological status was fixed as 3 days after weaning. In the present study, the possible roles of such changes in tissue specific proliferation in uterus was examined. The proliferation marker Ki 67 protein (MKI67) and steroid receptors, ESR1, ESR2 and PGR were analyzed in the uterus exposed to chronic low-dose NP or DEHP.

\section{MATERIALS AND METHODS}

\section{Animals and administration}

All experimental animals were conducted in accordance with the Guide for the Care and Use of Laboratory Animals published by the National Institute of Health. CD-1 (ICR) mice were maintained under standard condition at the animal house of Sungshin University. Circadian rhythm was kept under the 14L:10D schedule with light-on at 06:00 and clean room system. Animals were fed food and drink as mentioned in Cha et al. (2017). In brief, estrogen-free rodent diet (2018 Teklad global 18\% protein rodent diets; ENVIGA, Madison, WI, USA) and water in glass bottles with stainless steel sipper tubes were offered ad libitum.

Administration of NP (Sigma-Aldrich, Cat \# 46018, CAS \# 84852-15-3) and DEHP (Sigma Aldrich Cat \# 36735) was followed OECD Guidelines for the Testing of Chemicals - Test No. 443. 10-12-week-old animals were 
given NP at a dose of 50 or $500 \mu \mathrm{g} / \mathrm{L}$ (NP50 and NP500, respectively) or DEHP at a dose of 133 or $1,330 \mu \mathrm{g} / \mathrm{L}$ (DEHP133 and DEHP1,330, respectively) dissolved in drinking water for 10 weeks, considering that a mouse drinks approximately 4-7 $\mathrm{mL}$ of water daily. Control group was given water without test substances. Estrous cycle was checked by vaginal smearing daily for first 2 weeks, then each normal cycling female was chosen and bred with a fertile male for 2 weeks ( $\mathrm{n}=10 /$ each group). Copulatory plug was checked daily. After 6 weeks, animals were used for examination.

\section{Uterus sampling}

Uteri were dissected immediately after sacrifice. One side uterine horn was stored at $-80^{\circ} \mathrm{C}$ until used for molecular biological analyses. The other side was fixed overnight in modified Bouin's solution (4\% paraformaldehyde in PBS $+0.16 \%$ picric acid). The fixed uteri were dehydrated with ethyl alcohol using Leica TP 1020, and embedded in paraffin using Leica EG $1150 \mathrm{H}$.

\section{Immunohistochemistry}

The paraffin-embedded uteri were cross-sectioned at 4 $\mu \mathrm{m}$ using Leica RM2245 microtome and mounted on glass slides. The tissues were deparaffinized with xylene and hydrated with alcohol series. Then, they were subjected to antigen retrieval in boiling $10 \mathrm{mM}$ sodium citrate buffer (pH 6.0) for $15 \mathrm{~min}$. Endogenous peroxidase activity was blocked with $0.3 \%$ hydrogen peroxide in $\mathrm{H}_{2} \mathrm{O}$ for $30 \mathrm{~min}$. MKI67 immunoreactivity was detected according to the Vectastain $\mathrm{ABC}$ kit method (Vector Laboratories, Inc., Burlingame, CA). Briefly, tissues were incubated with $1 \%$ normal blocking serum in PBS for $20 \mathrm{~min}$ and then incubated with mouse monoclonal Ki-67 antibody (dilution 1:200). After washed in PBS containing $0.1 \%$ triton X-100 (PBST) and PBS, tissues were incubated with anti-mouse IgG (Vector Laboratories, Inc., Burlingame, CA). Tissues were washed and incubated with avidin-biotin-complex reagent containing horseradish peroxidase for $30 \mathrm{~min}$. Tissues were washed and color development was achieved using DAB substrate. The tissues were counterstained with hematoxylin.

\section{Immunofluorescence}

Likewise, the paraffin-embedded uteri were cross-sectioned at $4 \mu \mathrm{m}$, deparaffinized and hydrated. Then, they were subjected to antigen retrieval in boiling $10 \mathrm{mM}$ sodium citrate buffer $(\mathrm{pH} 6.0)$ for $10 \mathrm{~min}$. The tissues were permeabilized with PBST for 5 min. Hydrophobic barriers were drawn surrounding the tissues with ImmEdge ${ }^{\text {TM }}$ Pen (Vector Laboratories, Inc., Burlingame, CA). For blocking, the tissues were incubated with $1 \%$ normal blocking serum in PBS for $1 \mathrm{~h}$, and then incubated with antibody of each ESR1, ESR2, or PGR for $1 \mathrm{~h}$ (Table 1). After washed in PBST and PBS, for PGR detection tissues were incubated with second antibodies for $1 \mathrm{~h}$ and washed, but for ESR1 or ESR2 this step was skipped because the first antibodies were fluorescence conjugated. The tissues were counterstained with YOYO-1 (Cat \#: Y3601, Invitrogen, Waltham, MA) for 15 min and mounted. Specific signaling of ESR1, ESR2, or PGR was observed under the fluorescence microscope (Zeiss Axio Observer Z1).

\section{Statistical analysis}

The data were presented as means \pm SED. Two proportion $z$-test was performed to determine difference in proportions of MKI67 positive cells between control and experimental groups. Statistical significance was considered at $p<0.05$.

\section{RESULTS}

\section{Tissue specific patterns of proliferation by chronic} low-dose DEHP and NP exposure

The proliferation marker MKI67 was used to evaluate the proliferation patterns of uterine endometrial cells. Few 
Table 1. Information of antibodies

\begin{tabular}{ccccc}
\hline \hline Antibody product name & Host & Working dilution & Company & Catalog number \\
\hline MKI67 Antigen & Mouse & $1: 200$ & Leica & NCL-Ki67-MM1 \\
$\begin{array}{c}\text { Estrogen Receptor alpha (ESR1) } \\
\text { antibody [E115] (Phycoerythrin) }\end{array}$ & Rabbit & $1: 200$ & Abcam & ab209288 \\
$\begin{array}{c}\text { Estrogen Receptor beta/NR3A2 (ESR2) } \\
\text { Antibody (14C8) [Alexa Fluor 405] }\end{array}$ & Mouse & $1: 200$ & Novusbio & NB200- \\
PR (PGR) (C-19) & Rabbit & $1: 200$ & Santa Cruz Biotech. & sc-538 \\
AMCA Anti-Rabbit IgG (H+L) & Goat & $1: 200$ & Vector Laboratories & CI-1000 \\
\hline
\end{tabular}

of the luminal and glandular epithelial cells and stromal cells were positive to MKI67 antibody. The number of MKI67 stained stromal cells was significantly increased $(p<0.05)$ in all the DEHP groups and $50 \mu \mathrm{g} / \mathrm{L}$ NP group than the control (Fig. 1A-E, F). In glandular epithelium, the number of MKI67 positive cells was significantly less $(p<0.05)$ in all the DEHP groups than the control. However, the number of MKI67 positive glandular epithelial cell was not different or increased $(p<0.05)$ at 50 and $500 \mu \mathrm{g} / \mathrm{L}$ NP group, respectively (Fig. 1A-E, G). In luminal epithelial cells, the number of MKI67 positive cells was decreased at $1,330 \mu \mathrm{g} / \mathrm{L}$ DEHP group $(p<0.05)$ and $500 \mu \mathrm{g} / \mathrm{L}$ NP group $(p<0.05)$. On the other hand, the MKI67 positive cells were detected in $50 \mu \mathrm{g} / \mathrm{L} \mathrm{NP}$ group more than the control ( $p<0.05$; Fig. 1 A-E, H).

\section{Uterine endometrial tissue specific localization of} the steroid hormone receptors by chronic low-dose DEHP and NP exposure

ESR1 was localized in nuclei of endometrial cells of control mice uterus (Fig. 2, Table 2). However, its localization was changed by the administration of DEHP and NP. It was localized in nucleus and cytoplasm of both glandular and luminal epithelial cells at the $133 \mu \mathrm{g} / \mathrm{L}$ DEHP or localized only cytoplasm at the $1,330 \mu \mathrm{g} / \mathrm{L}$ DEHP and all the NP groups. In stromal cells, the ESR1 was localized only in nucleus without exception (Fig. 2, Table 2).

ESR2 was localized in the nucleus of stromal cells and in the cytoplasm of glandular epithelial cells. It was detected in both cytoplasm and nucleus of luminal epithelial cells. Administration of $133 \mu \mathrm{g} / \mathrm{L}$ DEHP caused relocalization of it to cytoplasm and nucleus but 1,330 $\mu \mathrm{g} / \mathrm{L}$ DEHP relocalized it only at cytoplasm in luminal epithelial cells. NP administration gave same result with $1,330 \mu \mathrm{g} / \mathrm{L}$ DEHP (Fig. 3, Table 2).

PGRs were localized in both cytoplasm and nucleus of stromal cells but only in cytoplasm of epithelial cells of gland and luminal epithelium. $133 \mu \mathrm{g} / \mathrm{L}$ DEHP administration caused the relocalization of PGRs to nucleus and cytoplasm of epithelial cells of gland and lumen but only to nucleus of stromal cells. DEHP had same effect on the stromal cell for the restriction the localization of PGRs at nucleus. $50 \mu \mathrm{g} / \mathrm{L}$ and $500 \mathrm{ng} / \mathrm{L}$ NPs exerted of same patterns with that of $133 \mu \mathrm{g} / \mathrm{L}$ and $1,330 \mu \mathrm{g} / \mathrm{L}$ DEHP, respectively (Fig. 4, Table 2).

3. Change of the colocalization patterns between steroid receptors by chronic low-dose NP and DEHP exposure

Colocalization of the steroid hormone receptors gives 

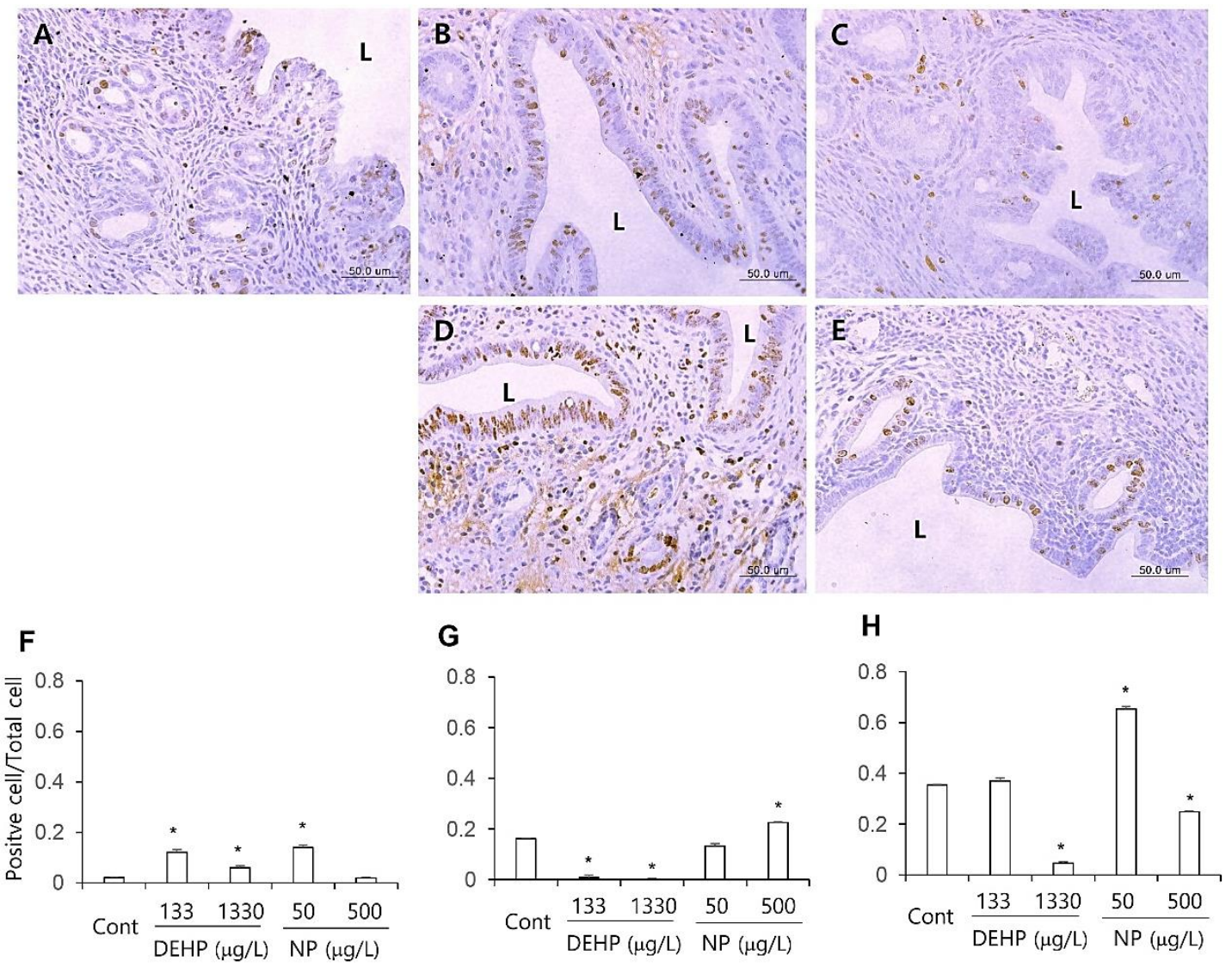

Fig. 1. Tissue specific localization of MKI67 localization in mouse uterus treated with DEHP and NP administration

Some of the localized cells came from different tissues of the control. Immunofluorescence was performed and the images were analyzed with confocal microscope. Representative immunohistochemistry conducted uteri. (A) control, (B) $133 \mu \mathrm{g} / \mathrm{L}$ DEHP, (C) 1,330 $\mu \mathrm{g} / \mathrm{L}$ DEHP, (D) $50 \mu \mathrm{g} / \mathrm{L} \mathrm{NP}$, (E) $500 \mu \mathrm{g} / \mathrm{L}$ NP. The ratio of MKI67 positive cells to total cell in the given fields of uterine sections ( 7 field/section, 3 section/mouse, $n=5$ ) were presented in $\mathrm{F}$ H. (F) stroma, (G) glandular epithelium, (H) luminal epithelium. L, lumen. Data are presented as means \pm SE. * $p<0.05$. DEHP, di(2-ethylhexyl) phthalate; NP, nonylphenol.

information for the proliferation regulation in uterine endometrium, so the colocalization of ESRs and PGR was analyzed. ESR1 and ESR2 were localized as shown in Fig. 2 and 3, and Table 2. They were colocalized at luminal epithelial cells and subepithelial stromal cells in control group (Fig. 5). ESR1 and ESR2 were colocalized as shown in control at the NP and DEHP groups in the chemical and dose dependent manners (Fig. 5). We examined the colocalization of the ESR1 and PGRs and got same result with the colocalizaiton between ESR1 and ESR2. Colocalization of ESR1 and PGR were detected in both epithelial cells and stroma cells. ESR1 and PGR were strongly stained in endometrium compared with the other groups (Fig. 6). In the case of ESR2 and PGR, they were not colocalized at endometrium in all groups (Fig. 7).

\section{DISCUSSION}

The results of this study are interesting, because the localization of ESRs and PGRs can be modulated by chronic low-dose NP and DEHP exposure. In addition to uterus (Kurita et al., 1998; Tibbetts et al., 1998), it was reported that the expressions of ESR1 and 2 and PGRs depend on the ligand levels in ventrolateral division of the ventromedial 

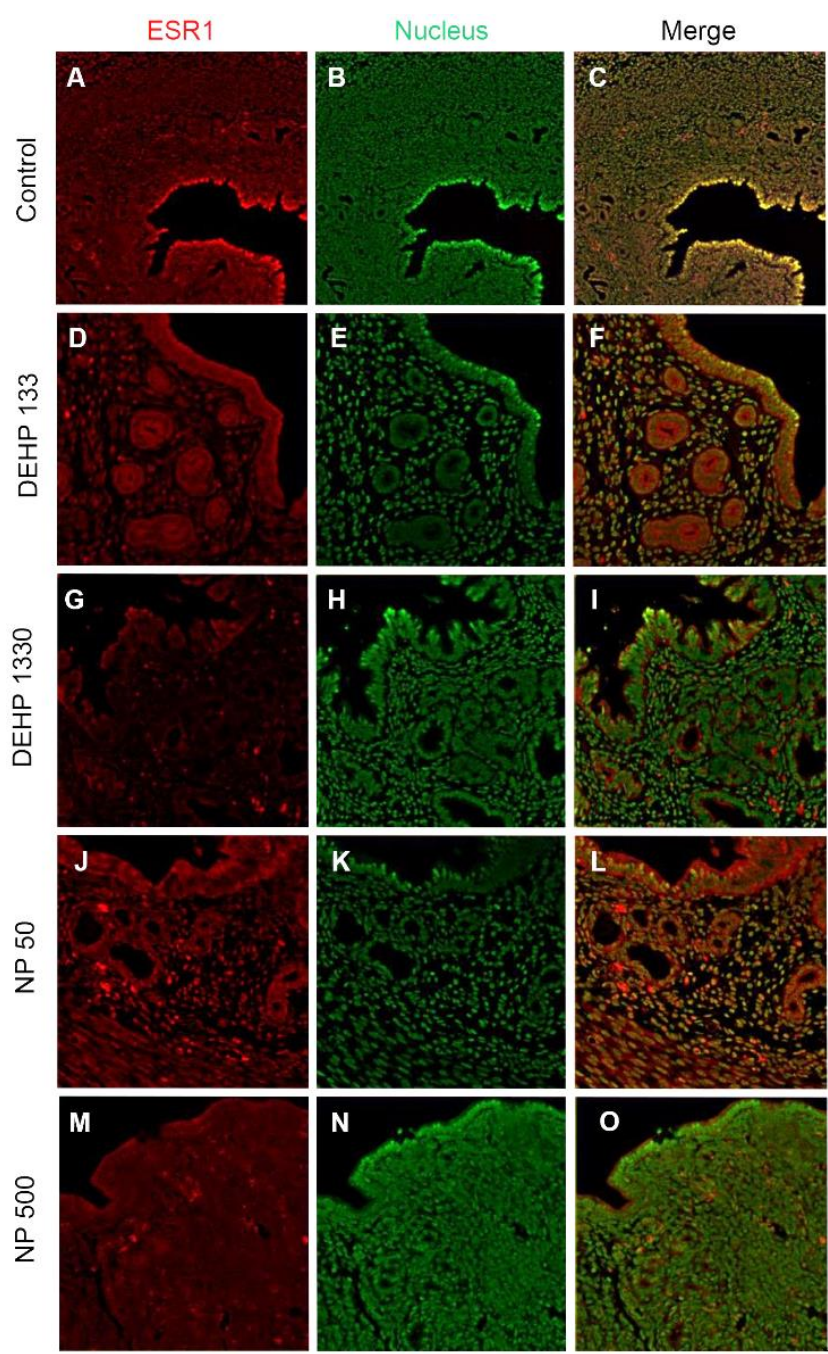

Fig. 2. Tissue specific localization of ESR1 by the treatment with DEHP and NP in mouse uterus. Some of the localized cells came from different tissues of the control. Immunofluorescence was performed with target specific antibodies and the images were analyzed with confocal microscope. (A-C) control, (D-F) $133 \mu \mathrm{g} / \mathrm{L}$ DEHP, (G-I) 1,330 $\mu \mathrm{g} / \mathrm{L}$ DEHP, (J-L) $50 \mu \mathrm{g} / \mathrm{L} \mathrm{NP},(\mathrm{M}-\mathrm{O}) 500 \mu \mathrm{g} / \mathrm{L}$ NP. (A, D, G, J, (B, E, H, K, N) nuclei presented by YOYO-1, (C, $\mathrm{F}, \mathrm{I}, \mathrm{L}, \mathrm{O})$ merged image. ESR1, estrogen receptor 1; DEHP, di(2-ethylhexyl) phthalate; NP, nonylphenol.

nucleus of the hypothalamus (VMN) (Lauber et al., 1990; Sá et al., 2015; Sá \& Fonseca, 2017). Recently, the physiological effects of EDCs with low doses which are in ranges of environmental levels, is one of the hot issue (Gore et al.,

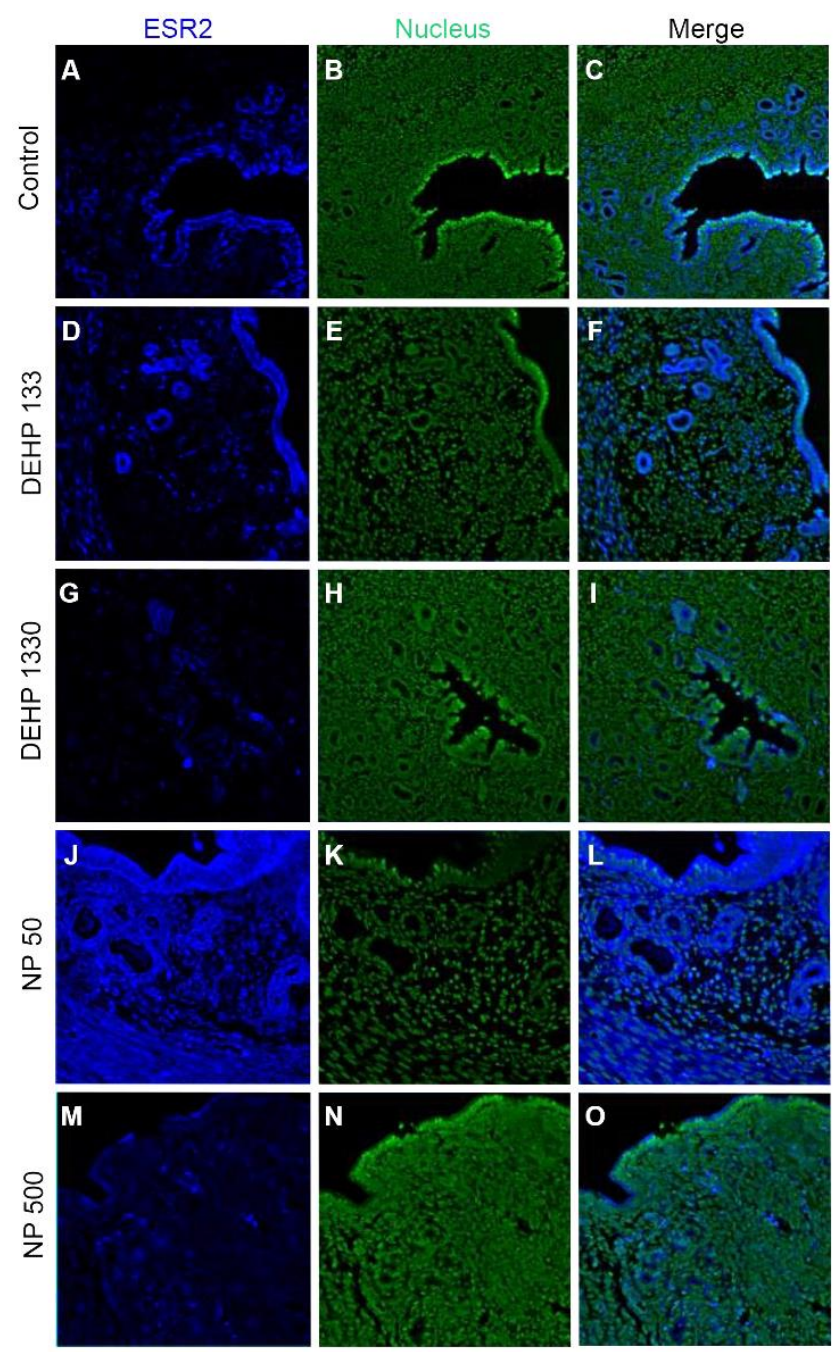

Fig. 3. Tissue specific localization of ESR2 in mouse uterus by DEHP and NP administration. Some of the localized cells came from different tissues of the control. Immunofluorescence was performed with target specific antibodies and the images were analyzed with confocal microscope. (A-C) control, (D-F) $133 \mu \mathrm{g} / \mathrm{L}$ DEHP, (G-I) 1,330 $\mu \mathrm{g} / \mathrm{L}$ DEHP, (J-L) $50 \mu \mathrm{g} / \mathrm{L}$ NP, (M-O) 500 $\mu \mathrm{g} / \mathrm{L}$ NP. (A, D, G, J, M) ESR2, (B, E, H, K, N) nuclei presented by YOYO-1, (C, F, I, L, O) merged image. ESR2, estrogen receptor 2; DEHP, di(2ethylhexyl) phthalate; NP, nonylphenol.

2015). In our previous reports, the low-dose chronic exposure of DEHP and NP was suggested as a possible modulator in physiology of reproductive tracts (Cha et al., 2017; Kim et al., 2018; Kim et al., 2019). The results showed a 
Table 2. Tissue specific localization of ESR1, ESR2 and PGR in mouse uterus that were treated with DEHP or NP. Quantification is presented by the number of + or - , negative

\begin{tabular}{|c|c|c|c|c|c|c|c|c|c|c|}
\hline & \multirow{2}{*}{$\mu g / L$} & \multicolumn{3}{|c|}{ ESR1 } & \multicolumn{3}{|c|}{ ESR2 } & \multicolumn{3}{|c|}{ PGR } \\
\hline & & St & GE & LE & St & GE & LE & St & GE & LE \\
\hline \multirow{2}{*}{ Contl } & Nucleus & +++ & +++ & +++ & ++ & - & ++ & ++ & - & - \\
\hline & Cytoplasm & - & - & - & - & +++ & +++ & ++ & +++ & +++ \\
\hline \multirow{2}{*}{$\begin{array}{c}\text { DEHP } \\
133\end{array}$} & Nucleus & +++ & +++ & +++ & ++ & ++ & ++ & +++ & +++ & +++ \\
\hline & Cytoplasm & - & +++ & +++ & - & +++ & +++ & - & +++ & +++ \\
\hline \multirow{2}{*}{$\begin{array}{c}\text { DEHP } \\
1330\end{array}$} & Nucleus & + & - & - & + & - & - & + & - & - \\
\hline & Cytoplasm & - & +++ & +++ & - & +++ & +++ & - & +++ & +++ \\
\hline \multirow{2}{*}{ NP 50} & Nucleus & +++ & - & - & +++ & - & - & +++ & +++ & +++ \\
\hline & Cytoplasm & - & +++ & +++ & - & +++ & +++ & - & +++ & +++ \\
\hline \multirow{2}{*}{$\begin{array}{l}\text { NP } \\
500\end{array}$} & Nucleus & +++ & - & - & +++ & - & - & + & - & - \\
\hline & Cytoplasm & - & +++ & +++ & - & +++ & +++ & - & +++ & +++ \\
\hline
\end{tabular}

St, stroma; GE, glandular epithelium; LE, luminal epithelium; Cont, control.

ESR1, estrogen receptor 1; ESR2, estrogen receptor 2; PGR, progesterone receptor; DEHP, di(2-ethylhexyl) phthalate; NP, nonylphenol.

chronic low-dose NP or DEHP works as estrogen-like messengers in uterus with their own specific gene expressionregulation patterns. Interestingly, the expression levels of Esr1, Esr2, and Pgr mRNAs were different by the NP or DEHP administration (Kim et al., 2018). It is well known that the expression of those steroid hormone receptors depends on the physiological needs in uterus, because the endometrial cell types undergo significant estrogen- and progesterone-dependent changes for pregnancy (Marcus, 1974; Tibbetts et al.,1998; Cha et al., 2012). Based on the physiological status (3 days after weaning of their pup) it should be almost similar expression profiles but those are different. Those suggest that the chronic low-dose expose of some chemicals could be cause of the change of the expression patterns of steroid hormonal receptors in a specific tissue.

The uterus consists of heterogeneous cell types (stromal cell, luminal epithelial cell, glandular epithelial cell, smooth muscle cell, endothelial cell, immune cells, etc.). Proliferation and differentiation in each compartment are changed primarily by systemic estrogen and progesterone (Weihua et al., 2000; Tsai et al., 2002; Yilmaz \& Bulun, 2019). The opposite actions between estrogen and progesterone are well established in uterus (Katzenellenbogen, 1980). Progesterone stimulates stromal cell proliferation and differentiation but estrogen inhibits inflammatory stimulus in stroma (Lydon et al., 1995, 1996; Pawar et al., 2015). Estrogen induces epithelial and stromal cell proliferation. Immature 21-day-old mouse treated with $\mathrm{E}_{2}$ (a dose of 50 $\mu \mathrm{g} / \mathrm{kg} /$ day for 3 days) showed an increase of MKI67 posi- 

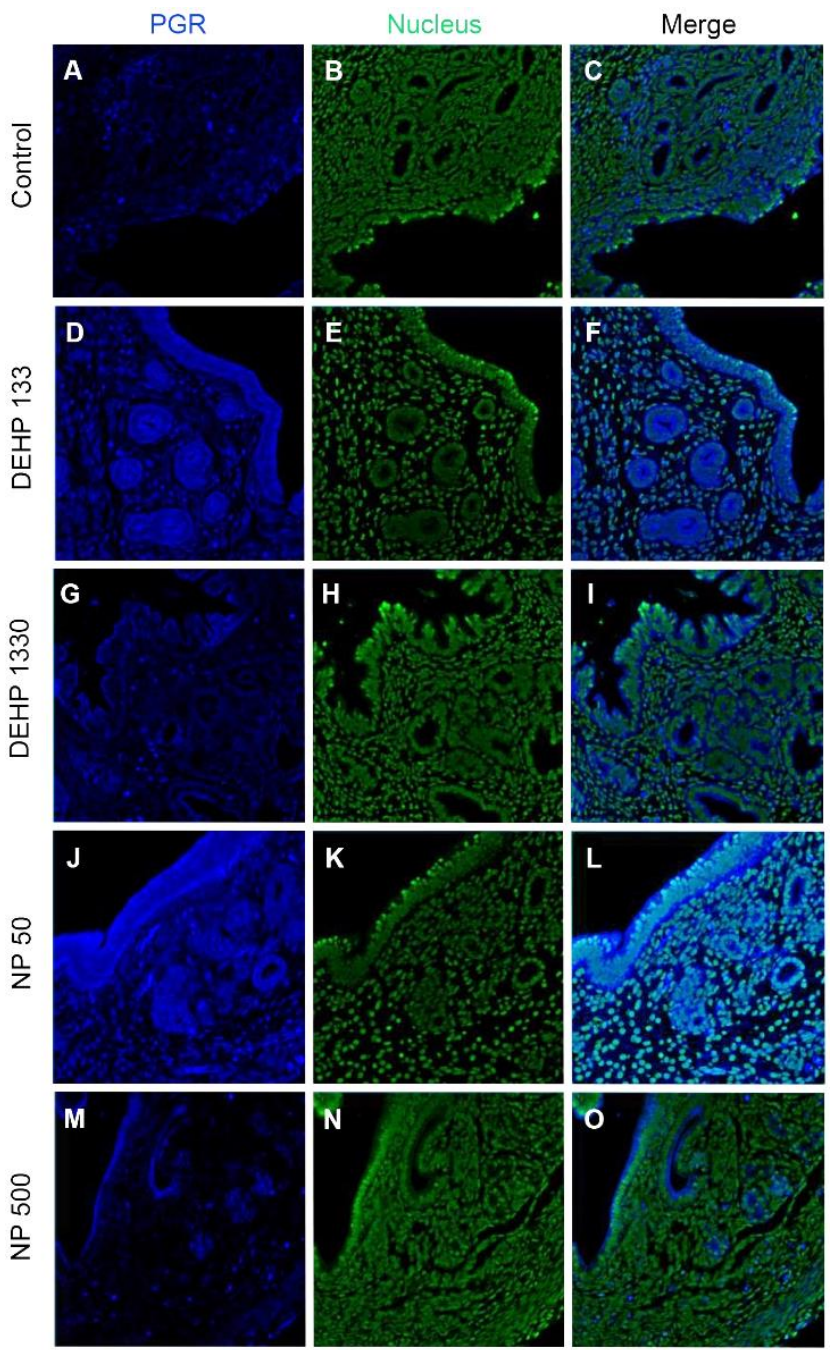

Fig. 4. Tissue specific localization of $P G R$ in mouse uterus by DEHP and NP administration. Some of the localized cells came from different tissues of the control. Immunofluorescence was performed with target specific antibodies and the images were analyzed with confocal microscope. (A-C) control, (D-F) $133 \mu \mathrm{g} / \mathrm{L}$ DEHP, (G-I) 1,330 $\mu \mathrm{g} / \mathrm{L}$ DEHP, (J-L) $50 \mu \mathrm{g} / \mathrm{L}$ NP, (M-O) $500 \mu \mathrm{g} / \mathrm{L}$ NP. (A, D, G, J, M) PGR, (B, E, H, K, N) nuclei presented by YOYO-1, (C, F, I, L, O) merged image. PGR, progesterone receptor; DEHP, di(2-ethylhexyl) phthalate; NP, nonylphenol.

tive cells in uterus from $2.3 \pm 1.0 \%$ to $14.5 \pm 4.7 \%$ of luminal epithelial cells (Weihua et al., 2000). In an in vitro study, human endometrial stromal cells were proliferated in response to $\mathrm{E}_{2}$ (Tsai et al., 2002). In this study, the pro-

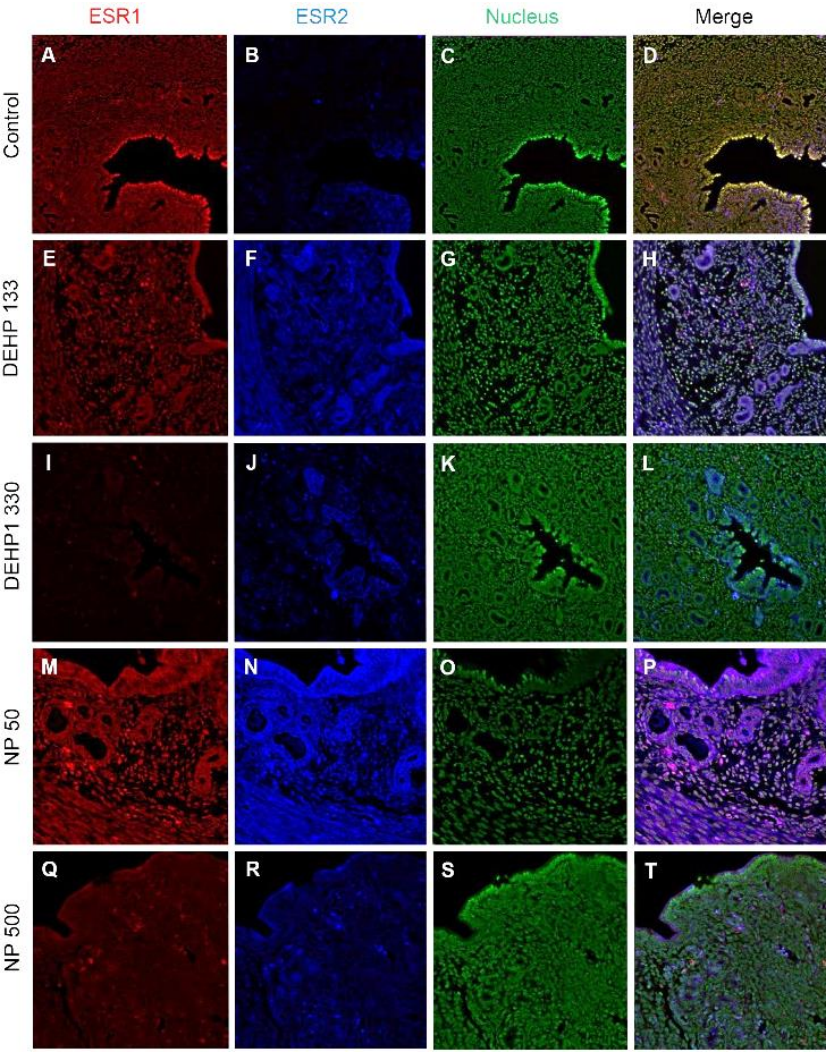

Fig. 5. Microfluorophotography of ESR1 and ESR2 in mouse uterus. Representative immunofluorescence conducted uteri are shown (magnification, $\times 100$ ). Colocalization of ESR1 and ESR2 was observed in luminal epithelial cells and stromal cells in a chemical and dose dependent manners. (A-D) control, (E-H) DEHP $133 \mu \mathrm{g} / \mathrm{L}$, (I-L) DEHP 1,330 $\mu \mathrm{g} / \mathrm{L},(\mathrm{M}-\mathrm{P}) \mathrm{NP} 50 \mu \mathrm{g} / \mathrm{L},(\mathrm{Q}-\mathrm{T}) \mathrm{NP} 500 \mu \mathrm{g} / \mathrm{L}$. (A, E, I, M, Q) ESR1, (B, F, J, N, R) ESR2, (C, G, K, $\mathrm{O}, \mathrm{S})$ nuclei presented by YOYO-1, (D, H, L, P, T) merged photomicrograph. ESR1, estrogen receptor 1; ESR2, estrogen receptor 2; DEHP, di(2ethylhexyl) phthalate; NP, nonylphenol.

portion of MKI67 positive cells in stroma was increased by 133 and $1,330 \mu \mathrm{g} / \mathrm{L}$ DEHP, and $50 \mu \mathrm{g} / \mathrm{L}$ NP exposure. Such results are similar with the recent reports of Nowark group for proliferation of epithelial and stromal cells (Richardson et al., 2018). In this study, we could evaluate the tissue specific localization or colocalization of steroid hormone receptors. ESR1 was localized strongly at nucleus of stroma and at nucleus and cytoplasm of the 


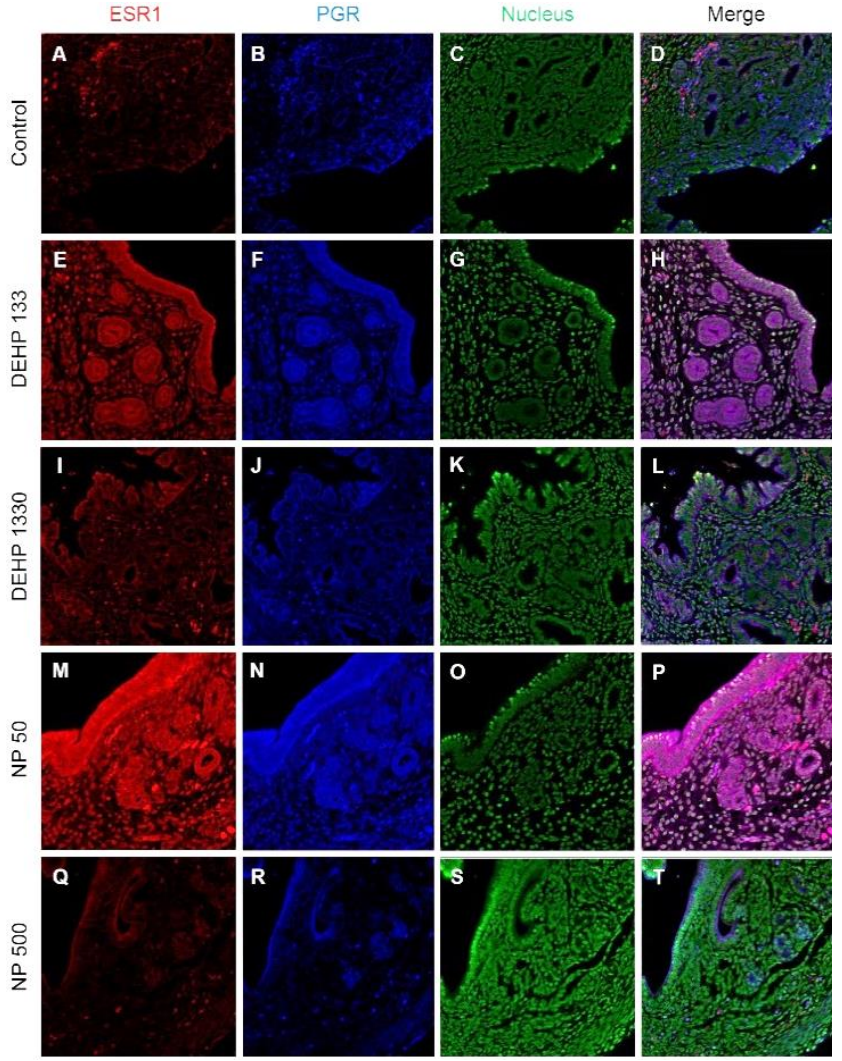

Fig. 6. Microfluorophotography of ESR1 and PGR in mouse uterus. Representative immunofluorescence conducted uteri are shown (magnification, $\times 100$ ). ESR1 and PGRs were colocalized at the most of the stained cells in control and the NP and DEHP groups in a chemical and dose dependent manners. (A-D) control, (E-H) DEHP $133 \mu \mathrm{g} / \mathrm{L}$, (I-L) DEHP $1,330 \mu \mathrm{g} / \mathrm{L},(\mathrm{M}-\mathrm{P}) \mathrm{NP} 50 \mu \mathrm{g} / \mathrm{L},(\mathrm{Q}-\mathrm{T}) \mathrm{NP} 500$ $\mu \mathrm{g} / \mathrm{L} .(\mathrm{A}, \mathrm{E}, \mathrm{I}, \mathrm{M}, \mathrm{Q}) \mathrm{ESR} 1,(\mathrm{~B}, \mathrm{~F}, \mathrm{~J}, \mathrm{~N}, \mathrm{R})$ PGR, (C, G, K, O, S) nuclei presented by YOYO-1, (D, $\mathrm{H}, \mathrm{L}, \mathrm{P}, \mathrm{T})$ merged photomicrograph. ESR1, estrogen receptor 1; PGR, progesterone receptor; NP, nonylphenol; DEHP, di(2-ethylhexyl) phthalate.

epithelial cells of gland and lumen in $133 \mu \mathrm{g} / \mathrm{L}$ DEHP exposure group. The intensity of each nuclear receptor was different each other by the administered chemicals and dose. Our earlier study demonstrated that mouse uterine endometrial thickness was increased by 133 and 1,330 $\mu \mathrm{g} / \mathrm{L}$ DEHP administration and the wet weight at $133 \mu \mathrm{g} / \mathrm{L}$ DEHP group (Kim et al., 2018). It may be the results of the changes in expression patterns of those nuclear receptors

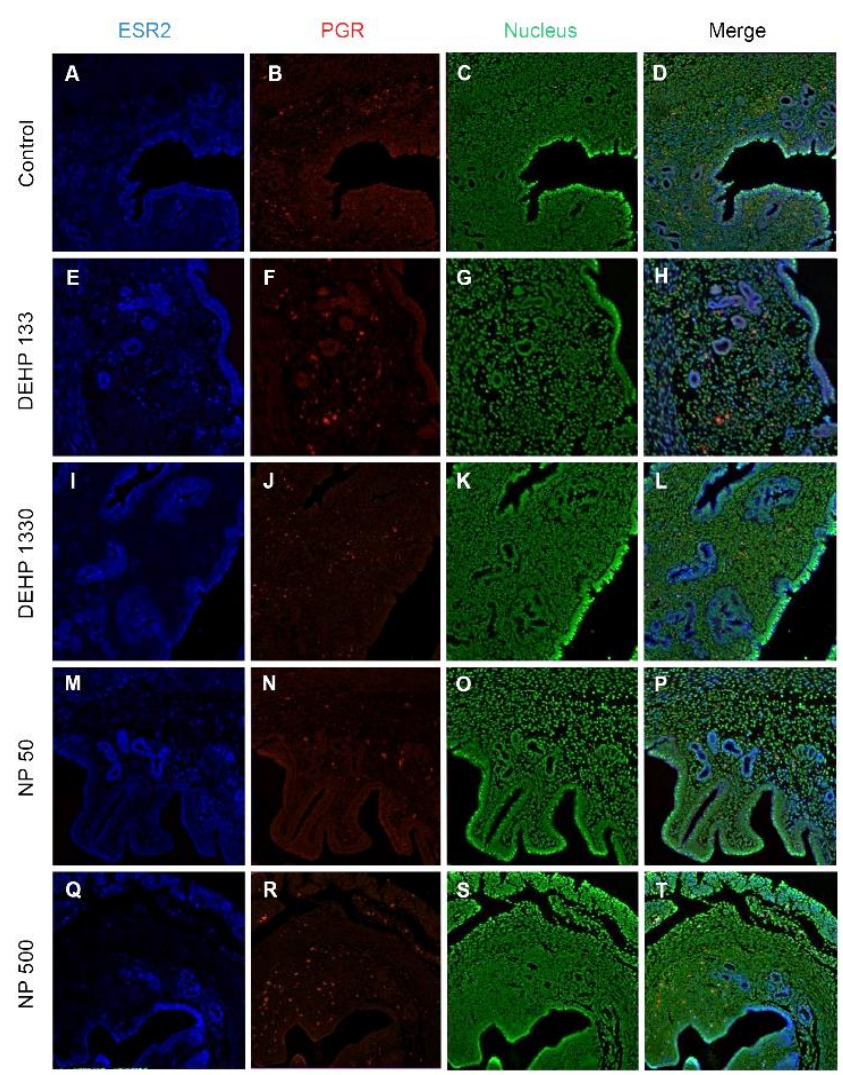

Fig. 7. Microfluorophotography of ESR2 and PGR in mouse uterus. Representative immunofluorescence conducted uteri are shown (magnification, $\times 100)$. ESR2 and PGR were not colocalized in the same cells in both stromal and epithelial cells. In $133 \mu \mathrm{g} / \mathrm{L}$ DEHP group, the ESR2 and PGR were colocalized in some epithelial cells. (A-D) control, $(\mathrm{E}-\mathrm{H}) \mathrm{DEHP}$ $133 \mu \mathrm{g} / \mathrm{L}$, (I-L) DEHP 1,330 $\mu \mathrm{g} / \mathrm{L}$, (M-P) NP 50 $\mu \mathrm{g} / \mathrm{L},(\mathrm{Q}-\mathrm{T}) \mathrm{NP} 500 \mu \mathrm{g} / \mathrm{L}$. (A, E, I, M, Q) ESR2, $(\mathrm{B}, \mathrm{F}, \mathrm{J}, \mathrm{N}, \mathrm{R})$ PGR, (C, G, K, O, S) nuclei presented by YOYO-1, (D, H, L, P, T) merged photomicrograph. ESR2, estrogen receptor 2; PGR, progesterone receptor; DEHP, di(2-ethylhexyl) phthalate; NP, nonylphenol.

and interaction of them in transcription (Tibbetts et al., 1998; Yilmaz \& Bulun, 2019).

In glandular epithelium, the number of glands was increased in $133 \mu \mathrm{g} / \mathrm{L}$ DEHP administration but decreased in $50 \mu \mathrm{g} / \mathrm{L}$ and NP $500 \mu \mathrm{g} / \mathrm{L} \mathrm{NP}$ groups in a dose dependent manner (Kim et al., 2018). 30-day expose of DEHP (0.6 or $6 \mu \mathrm{g} /$ day) caused an increase in the number of glands in 
CD-1 mice (Richardson et al., 2018). The administered dose of Richardson et al (2018) was similar with the dose of our study. Interestingly, as seen in the results, the MKI67 positive cell ratio was significantly low in all DEHP administered groups but high in $1,330 \mu \mathrm{g} / \mathrm{L}$ group. The number of glands is the results of the proliferation and differentiation of glandular epithelium. As expected, ESR1 and ESR2 were not localized in the nucleus but in the cytoplasm of the epithelial cells of gland in all NP groups. PGRs were localized at cytoplasm and nucleus in $50 \mu \mathrm{g} / \mathrm{L}$ NP group but not in $500 \mu \mathrm{g} / \mathrm{L}$. In $133 \mu \mathrm{g} / \mathrm{L}$ DEHP administered group, ESR1 was translocated into cytoplasm, and coexisted at both nucleus and cytoplasm with similar intensity. On the other hand, ESR2 was translocated into nucleus, and coexisted at both nucleus and cytoplasm with similar intensity. PGR was also translocated into nucleus. However, in the $1,330 \mu \mathrm{g} / \mathrm{L}$ DEHP administered group, ESR1, ESR2, and PGR were localized only at cytoplasm. Those results suggest that the number of the gland may be the results of the localization of the NRs in glandular epithelial cells and the environment as suspected from the previous reports (Cato et al., 1988; Tibbetts et al., 1998; Bulun et al., 2012; Yilmaz \& Bulun, 2019).

The expression pattern of ESR1 in 8-wk-old OVX PGR knockout mice is similar to that in wild-type mice regardless of $1 \mu \mathrm{g} \mathrm{E}_{2}$ injection for 4 days, indicating that localization of ESR1 is independent of PGR activity (Tibbetts et al., 1998). $E_{2}$ significantly increased the number of luminal epithelial cells expressing ESR1 and decreased stromal ESR1. ESR1 is highly expressed in the uterine epithelium and is a primary contributor in the proliferation of epithelial cells directly or indirectly (Grant-Tschudy \& Wira, 2005; Somasundaram et al., 2016). Esr1 null mice display an inability to respond to the proliferative and inflammatory stimuli of estrogen (Korach, 1994). Another studies demonstrated that although ESR1 localizes in the epithelium, proliferation of epithelial cells is mediated by paracrine factors which are secreted by stromal ESR1 in response to
E2. (Cooke et al., 1997). FGF 10 and BMP8a from stroma can control the epithelial cell proliferation by estrogen and its receptor (Cooke et al., 1997; Chung et al., 2015). On the other hand, the high concentration of $E_{2}(500 \mathrm{pg} / \mathrm{mL})$ stimulates the proliferation of epithelial cells through the expression of PGR and PGR membrane component 1 (PGRMC1) (Kempisty et al., 2015). Pgr null mice display estrogen-dependent hyperplasia of the uterine epithelium, stromal hypocellularity, and significant uterine inflammation (Lydon et al., 1995, 1996). In our previous study, ESR1 mRNA expression was enhanced by $2 \mu \mathrm{g} / \mathrm{kg} \mathrm{E}_{2}$ and $500 \mu \mathrm{g} / \mathrm{L}$ NP, but not $50 \mu \mathrm{g} / \mathrm{L}$ NP and DEHP (Kim et al., 2018). As seen in the results, in control group, ESR1 was found in almost every nucleus. However, in contrast to the control, in $133 \mu \mathrm{g} / \mathrm{L}$ DEHP group, ESR1 was strongly localized in cytoplasm than nuclei in epithelium. 1,330 $\mu \mathrm{g} / \mathrm{L}$ DEHP administration decreased the number of ESR1 positive cells in stroma and translocalized into cytoplasm. $50 \mu \mathrm{g} / \mathrm{L}$ and $500 \mu \mathrm{g} / \mathrm{L}$ NP also transferred its localization in epithelium from nuclei to cytoplasm. The colocalization of those NRs was different between the groups. Based on them, it is suggested that chronic low-dose expose of NP and DEHP could be cause the modification of the activity of the nuclear receptor in uterine tissues.

In 21-day-old mice ESR2 protein was localizes in uterine epithelium and stroma, and $\mathrm{E}_{2}$ treatment decreases ESR2 in stroma (Weihua et al., 2000). Estrogen receptors, ESR1 and ESR2-mediate transcriptional effects of estrogen. ESR2 has an anti-uterotrophic effect and so attenuates effects of ESR1 (Weihua et al., 2000; Somasundaram et al., 2016). In our earlier study (Kim et al., 2018), ESR2 mRNA expression was not significantly changed by $\mathrm{E}_{2}$ but decreased by DEHP administration. In the protein levels, ESR2 was detected in the nuclei of control endometrial stroma in less positive cells compared with ESR1. ESR2 was also detected in cytoplasm of glandular epithelial cells and both cytoplasm and nuclei of luminal epithelium. Such localization patterns were changed by the administration of chronic low-dose NP and DEHP. 
PGR is expressed through $\mathrm{E}_{2}$-induced ESR1 action (Somasundaram et al., 2016). $\mathrm{E}_{2}$ induces PGR in stroma and glandular epithelial cells but decreases PGR in luminal epithelium (Tibbetts et al., 1998; Weihua et al., 2000). $E_{2}$ induces intense PGR staining in the stromal compartment with about half of the cells staining positively (Tibbetts et al., 1998). In our earlier study (Kim et al., 2018), PGR mRNA expression was increased by $E_{2}$ but decreased by $500 \mu \mathrm{g} / \mathrm{L}$ NP. The subcellular localization and tissue specific localization of PGR were modified by the chronic lowdose administration of NP and DEHP.

Based on the pleiotropic effects of estrogen and progesterone in the adult mouse uterus, the difference of the localized tissues suggests the possible role of chronic lowdose NP or DEHP as endocrine modulator without negative effects in reproduction. The localization of ESR1, ESR2, and PGR was different between groups. In addition, the colocalizaion patterns of NRs were modified by the administration of NP and DEHP. These results suggest that nuclear activation of steroid hormonal receptors is affected by NP and DEHP, resulting in change in cell proliferation by tissue interaction. Therefore, chronic exposure to lowdose NP or DEHP regulates uterine cell proliferation and localization of steroidal hormone receptors in dose-dependent manner and have adverse effect on uterus function.

\section{CONFLICT OF INTERESTS}

The authors declare no potential conflict of interest.

\section{ACKNOWLEDGEMENTS}

This study was supported by a grant of Sungshin University (2018).

\section{REFERENCES}

Bulun SE, Monsavais D, Pavone ME, Dyson M, Xue Q,
Attar E, Tokunaga H, Su E (2012) Role of estrogen receptor- $\beta$ in endometriosis. Semin Reprod Med 30:3945.

Cato AC, Heitlinger E, Ponta H, Klein-Hitpass L, Ryffel GU, Bailly A, Rauch C, Milgrom E (1988) Estrogen and progesterone receptor-binding sites on the chicken vitellogenin II gene: Synergism of steroid hormone action. Mol Cell Biol 8:5323-5330.

Cha S, Baek JW, Ji HJ, Choi JH, Kim C, Lee MY, Hwang YJ, Yang E, Lee SH, Jung HI, Cheon YP (2017) Disturbing effects of chronic low-dose 4-nonylphenol exposing on gonadal weight and reproductive outcome over one-generation. Dev Reprod 21:121-130.

Cha J, Sun X, Dey SK (2012) Mechanisms of implantation: Strategies for successful pregnancy. Nat Med 18:17541767.

Chung D, Gao F, Jegga AG, Das SK (2015) Estrogen mediated epithelial proliferation in the uterus is directed by stromal Fgf10 an Bmp8a. Mol Cell Endocrinol 400:48-60.

Cooke PS, Buchanan DL, Young P, Setiawan T, Brody J, Korach KS, Taylor J, Lubahn DB, Cunha GR (1997) Stromal estrogen receptors mediate mitogenic effects of estradiol on uterine epithelium. Proc Natl Acad Sci USA 94:6535-6540.

Danzo BJ, Shappell HW, Banerjee A, Hachey DL (2002) Effects of nonylphenol, 1,1-dichloro-2,2-bis ( $p$-chlorophenyl) ethylene ( $p, p^{\prime}$-DDE), and pentachlorophenol on the adult female guinea pig reproductive tract. Reprod Toxicol 16:29-43.

Davis BJ, Maronpot RR, Heindel JJ (1994) Di-(2-ethylhexyl) phthalate suppresses estradiol and ovulation in cycling rats. Toxicol Appl Pharmacol 128:216-223.

Gore AC, Chappell VA, Fenton SE, Flaws JA, Nadal A, Prins GS, Toppari J, Zoeller RT (2015) EDC-2: the endocrine society's second scientific statement on endocrine-disrupting chemicals. Endocr Rev 36:E1-E150. Grant-Tschudy KS, Wira CR (2005) Effect of oestradiol on 
mouse uterine epithelial cell tumour necrosis factor- $\alpha$ release is mediated through uterine stromal cells. Immunology 115:99-107.

Jobling S, Reynolds T, White R, Parker MG, Sumpter JP (1995) A variety of environmentally persistent chemicals, including some phthalate plasticizers, are weakly estrogenic. Environ Health Perspect 103:582-587.

Katzenellenbogen BS (1980) Dynamics of steroid hormone receptor action. Annu Rev Physiol 42:17-36.

Kempisty B, Wojtanowicz-Markiewicz K, Ziółkowska A, Budna J, Ciesiółka S, Piotrowska H, Bryja A, Antosik P, Bukowska D, Wollenhaupt K, Brüska M, Brussow KP, Nowicki M, Zabel M (2015) Association between progesterone and estradiol-17beta treatment and protein expression of pgr and PGRMC1 in porcine luminal epithelial cells: A real-time cell proliferation approach. J Biol Regul Homeost Agents 29:39-50.

Kim J, Cha S, Lee MY, Hwang YJ, Yang E, Ryou C, Jung HI, Cheon YP (2018) Chronic low-dose nonylphenol or di-(2-ethylhexyl) phthalate has a different estrogenlike response in mouse uterus. Dev Reprod 22:379-391.

Kim YB, Cheon YP, Lee SH (2019) Adverse effect of nonyphenol on the reproductive system in F1 male mice: A subchronic low-dose exposure model. Dev Reprod 23:93-99.

Korach KS (1994) Insights from the study of animals lacking functional estrogen receptor. Science 266:1524-1527.

Kurita T, Young P, Brody JR, Lydon JP, O/Malley BW, Cunha GR (1998) Stromal progesterone receptors mediate the inhibitory effects of progesterone on estrogeninduced uterine epithelial cell deoxyribonucleic acid synthesis. Endocrinology 139:4708-4713.

Lauber AH, Romano GJ, Mobbs CV, Pfaff DW (1990) Estradiol regulation of estrogen receptor messenger ribonucleic acid in rat mediobasal hypothalamus: An in situ hybridization study. J Neuroendocrinol 2:605-611.

Lee PC, Lee W (1996) In vivo estrogenic action of nonylphenol in immature female rats. Bull Environ Contam
Toxicol 57:341-348

Lorz PM, Towae FK, Enke W, Jackh R, Bhargava N, Hillesheim W (2012) Phthalic Acid and Derivatives. Ullmann's Encyclopedia of Industrial Chemistry, WileyVCH Verlag, Weinheim, German.

Lovekamp-Swan T, Davis B (2003) Mechanisms of phthalate ester toxicity in the female reproductive system. Environ Health Perspect 111:139-145.

Lydon JP, DeMayo FJ, Funk CR, Mani SK, Hughes AR, Montgomery CA, Shyamala G, Conneely OM, O’Malley BW (1995) Mice lacking progesterone receptor exhibit pleiotropic reproductive abnormalities. Genes Dev 9: 2266-2278.

Lydon JP, DeMayo FJ, Conneely OM, O’Malley B (1996) Reproductive phenotypes of the progesterone receptor null mutant mouse. J Steroid Biochem Mol Biol 56:6777.

Marcus GJ (1974) Mitosis in the rat uterus during the estrous cycle, early pregnancy, and early pseudopregnancy. Biol Reprod 10:447-452.

Pawar S, Laws MJ, Bagchi IC, Bagchi MK (2015) Uterine epithelial estrogen receptor- $\alpha$ controls decidualization via a paracrine mechanism. Mol Endocrinol 29:13621374.

Richardson KA, Hannon PR, Johnson-Walker YJ, Myint MS, Flaws JA, Nowak RA (2018). Di(2-ethylhexyl) phthalate (DEHP) alters proliferation and uterine gland numbers in the uteri of adult exposed mice. Reprod Toxicol 77:70-79.

Sa SI, Fonseca BM (2017) Dynamics of progesterone and estrogen receptor alpha in the ventromedial hypothalamus. J Endocrinol 233:197-207.

Sa SI, Fonseca BM, Teixeira N, Madeira MD (2015) Estrogen receptors $\alpha$ and $\beta$ have different roles in the induction and trafficking of progesterone receptors in hypothalamic ventromedial neurons. FEBS Journal 282: $1126-1136$

Scsukova S, Rollerova E, Mlynarcikova AB (2016) Impact 
of endocrine disrupting chemicals on onset and development of female reproductive disorders and hormonerelated cancer. Reprod Biol 16:243-254.

Somasundaram DB, Manokaran K, Selvanesan BC, Bhaskaran RS (2016) Impact of di-(2-ethylhexyl) phthalate on the uterus of adult Wistar rats. Hum Exp Toxicol 36:565-572.

Tibbetts TA, Mendoza-Meneses M, O’Malley BW, Conneely OM (1998) Mutual intercompartmental regulation of estrogen receptor and progesterone receptor expression in mouse uterus. Biol Reprod 59:1143-1152.

Tsai SJ, Wu MH, Chen HM, Chuang PC, Wing LYC (2002)
Fibroblast growth factor-9 is an endometrial stromal growth factor. Endocrinology 143:2715-2721.

Weihua Z, Saji S, Mäkinen S, Cheng G, Jensen EV, Warner M, Gustafsson JA (2000) Estrogen receptor (ER) $\beta$, a modulator of ER $\alpha$ in the uterus. Proc Natl Acad Sci USA 97:5936-5941.

Yilmaz BD, Bulun SE (2019) Endometriosis and nuclear receptors. Hum Reprod Update 25:473-485.

Zhang W, Yang J, Wang J, Xia P, Xu Y, Jia H, Chen Y (2007) Comparative studies on the increase of uterine weight and related mechanisms of cadmium and $\mathrm{p}$ nonylphenol. Toxicology 241:84-91. 